\title{
Analisis High Availability Pada Sistem Berbasis Teknologi Oracle Data Guard (Studi Kasus SIA-SAT UKSW)
}

\author{
Kristoko Dwi Hartomo, T. Arie Setiawan P., Sandy Pratama \\ Fakultas Teknologi Informasi, Universitas Kristen Satya Wacana \\ Jl. Diponegoro 52-60, Salatiga 50711, Indonesia \\ Email: kristoko@staff.uksw.edu
}

\begin{abstract}
High Availability on Oracle Data Guard-based System (Case Study: SIA-SAT UKSW). SIA-SAT is a subject administration system for UKSW collegian. Database SIASAT is backuped by autobackup system, and backup file sent directly to backup server at another building. Until these days, database SIA-SAT system still does not have a secondary database (backup) which can replace main database when failure is happening on main database.Oracle Data Guard System is a technology researched by Oracle to increase availability level on Oracle Database server. Every transaction is saved on main server and duplicated for standby database server. The advantages point of technology is standby database which indirectly becomes a backup server, and standby database can be used for replacing main database.The result of this research is the technology of Oracle Data Guard can increase availability level for a system Oracle Database. This condition can happen because standby database always duplicates data and is ready to replace primary database.
\end{abstract}

Keywords: availability, data guard, database distribution

\begin{abstract}
Abstrak. SIA-SAT adalah sebuah sistem administrasi mata kuliah untuk mahasiswa. Basis data SIA-SAT dicadangkan oleh sistem cadang otomatis, dan berkas cadangan tersebut dikirimkan secara langsung ke server cadangan yang terletak di gedung lain. Hingga saat ini, sistem basis data SIA-SAT masih belum memiliki basis data sekunder (cadangan) yang dapat menggantikan basis data utama jika kegagalan terjadi pada basis data utama. Oracle Data Guard System adalah sebuah teknologi yang diteliti oleh Oracle untuk meningkatkan tingkat ketersediaan pada Oracle Database server. Setiap transaksi disimpan pada server utama dan diduplikasi untuk standby database server. Manfaat dari teknologi ini adalah standby database secara tidak langsung menjadi server cadangan, dan standby database dapat digunakan untuk menggantikan basis data utama. Hasil dari penelitian ini adalah teknologi Oracle Data Guard dapat meningkatkan tingkat ketersediaan untuk sistem Oracle Database. Kondisi ini dapat tercapai karena standby database selalu menduplikasi data dan siap untuk menggantikan basis data primer.
\end{abstract}

Kata Kunci: ketersediaan, data guard, distribusi basis data

\section{Pendahuluan}

Basis data terkomputerisasi merupakan hal yang penting dalam organisasi modern. Masing-masing dari kita sebenarnya selalu berhubungan dengan basis data dalam kegiatan sehari-hari seperti: berbelanja di toko, transaksi keuangan pada Automated Teller Machine (ATM), memesan barang secara online, dan registrasi mata kuliah. Sebagian besar hidup kita adalah bagian dari perkembangan basis data terkomputerisasi dan teknologi basis data.

Teknologi basis data tidak hanya meningkatkan kinerja organisasi namun juga kualitas pengambilan keputusan yang mempengaruhi hidup orang lain. Basis data menyimpan sebuah aliran data tentang banyak aspek seperti: data diri seseorang, pemakaian pulsa telpon, histori kredit, dan masih banyak lagi. Karena itu, basis data dapat disebut hal yang sangat penting dikarenakan menyimpan banyak data-data penting yang tidak boleh hilang. 
Ada banyak hal yang dapat menyebabkan data hilang seperti: bad sector pada hard disk, listrik yang kurang stabil, program yang rusak (corrupt), virus komputer, kesalahan user waktu menghapus data, dan lain-lain. Dengan situasi seperti, teknologi backup dan recovery muncul untuk mengatasi hal-hal tersebut. Kerusakan fisik maupun non-fisik pada server basis data dapat dikembalikan ke kondisi semula dengan teknologi backup.

UKSW adalah salah satu perguruan tinggi yang telah menerapkan teknologi basis data sebagai pendukung kinerja operasional sehari-hari, dari urusan administrasi sampai registrasi mata kuliah untuk mahasiswa. Sehingga, data tersebut akan bernilai sangat tinggi, dan sangat penting. Untuk menjaga data tersebut, maka akan dilakukan proses backup. Namun, ada satu hal yang penting lagi, yaitu faktor ketersediaan (availability). Jika sebuah server basis data dapat dikembalikan kapan saja dari backup yang ada, tetapi akan memakan waktu yang cukup lama. Untuk itulah dibutuhkan sebuah sistem yang dapat menjaga ketersediaan layanan basis data untuk sistem SIA-SAT.

Dhanu Indira Bharwara adalah salah satu yang pernah meneliti tentang high availability, judul penelitiannya adalah "Cluster High Availability Pada Server LTSP" yang bertujuan untuk menangani komputasi server dengan thin client. Baik server utama dan cadangan, keduanya memiliki aplikasi yang memonitoring keadaan masing-masing server, jika ada komputer yang rusak, aplikasi monitor akan langsung mengaktifkan server cadangan.

Teknologi high availability adalah teknologi yang dapat diterapkan pada server apa saja, dalam penelitian Bharwara, high availability di implementasikan pada web server, agar mempunyai fungsionalitas yang tinggi. High availability digunakan untuk menggantikan web server yang satu saat server tersebut rusak.

High availability berbeda dengan load balancing, meskipun jumlah komputer yang digunakan sama untuk menambah kemampuan, namun server pada load balancing bekerja bersama-sama, sedangkan pada high availability, setiap server akan bekerja satu-satu, standby server akan bekerja pada saat server primer down.

\section{Tinjauan Pustaka}

\subsection{Basis Data}

Basis data adalah sebuah kumpulan data yang persistent yang dapat dibagi dan saling berhubungan menurut Mannino. Data yang persistent dapat diartikan sebagai data yang disimpan dalam tempat yang aman atau stabil. Aman dalam arti data yang disimpan tidak dapat berubah atau hilang kecuali data tersebut memang diubah atau dihapus. Stabil mempunyai arti data disimpan dalam media yang tidak mudah rusak. Dapat dibagi berarti sebuah basis data mempunyai kemampuan untuk melayani banyak pengguna dan mempunyai banyak kegunaan (Saputra). Saling berhubungan adalah data dapat disimpan dalam unit yang berbeda, namun dapat terhubung menjadi sebuah gambaran data yang sempurna.

Basis data semakin berkembang, sampai saat ini basis data harus dapat menyimpan data yang berukuran gigabyte, dikarenakan kebutuhan yang semakin tinggi. Disamping itu, semakin tinggi kebutuhan penyimpanan akan menyebabkan tingkat penggunaan meningkat yang menyebabkan persentase kerusakan akan menjadi lebih tinggi. Pada saat terjadi kerusakan yang menyebabkan basis data down, saat itulah tingkat high availability dari suatu server menurun. Hal ini disebabkan banyak pengguna yang harus menunggu hingga basis data tersebut dapat dipergunakan kembali.

\subsection{High Availability}

High availability adalah sebuah desain protokol sistem dan implementasi dari sebuah jaminan tentang sebuah kepastian dari kelanjutan operasional dalam sebuah periode yang ditentukan (Koopmann). Kata availability mengacu kepada kemampuan sekelompok pengguna agar dapat mengakses ke dalam sistem seperti menambah pekerjaan baru, mengubah pekerjaan 
yang sebelumnya, atau mengumpulkan hasil dari pekerjaan yang sebelumnya. Jika pengguna tidak dapat mengakses sistem, dapat dikatakan sistem tersebut tidak tersedia (unavailable). Secara umum variabel yang digunakan untuk memutuskan sebuah sistem available atau unavailable adalah downtime.

Rumus 1. Avaliability

availability $=\frac{\text { uptime }(\text { MTBF })}{\text { uptime }(\text { MTBF })+\operatorname{downtime}(\text { MTTR })}$

Tabel 1. Pengukuran Availability (Han)

\begin{tabular}{cc}
\hline Uptime (persen) & Downtime / Tahun \\
\hline 97.9494 & 7.3 hari \\
\hline 98.9747 & 3.65 hari \\
\hline 99.4874 & 43.8 jam \\
\hline 99.7949 & $17.52 \mathrm{jam}$ \\
\hline 99.8975 & $8.76 \mathrm{jam}$ \\
\hline 99.9898 & $52.3 \mathrm{menit}$ \\
\hline
\end{tabular}

Pada rumus 1, availability adalah satuan waktu sistem untuk memulihkan diri jika terjadi failure. MTBF (Mean Time Between Failure) adalah waktu rata-rata antara failure yang ke $n$ dengan failure ke $n$-1. MTTR (Mean Time To Recover / Repair) adalah waktu rata-rata sistem yang dibutuhkan untuk pulih dari keadaan failure. Tabel 1 adalah tabel pengukuran availability.

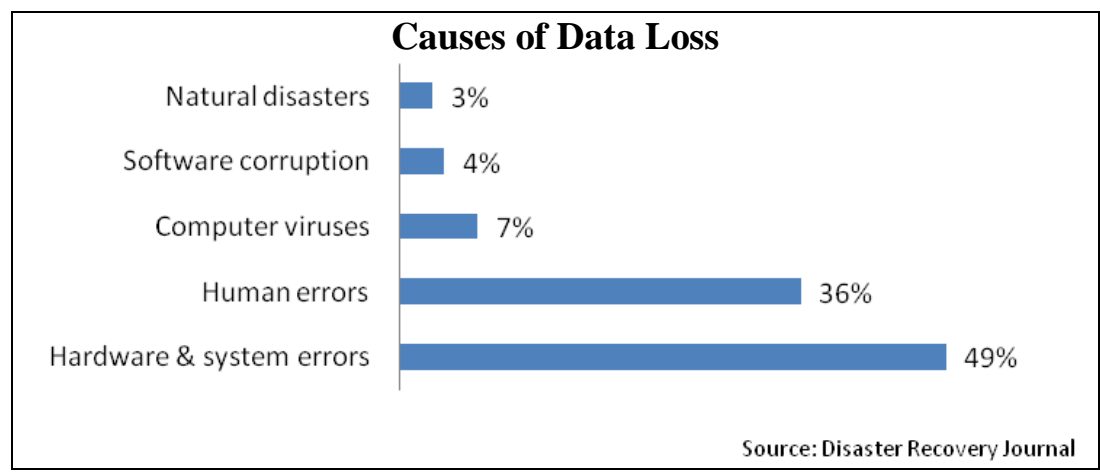

Gambar 1. Persentase Penyebab Kehilangan Data

\subsection{Oracle Database}

Oracle terbagi menjadi 2 bagian utama, yaitu memory structure dan storage structure. Saat sebuah basis data dijalankan dalam sebuah server basis data, Oracle akan mengalokasikan sejumlah shared memory yang disebut System Global Area (SGA) dan menjalankan sejumlah background process. Gabungan antara SGA dan background process disebut Oracle instance.

Arsitektur Oracle terbagi menjadi 2 bagian besar yaitu instance dan database file (Greenberg). Instance merupakan kumpulan proses-proses yang bekerja dibelakang Oracle. Instance bekerja untuk mengatur pemakaian prosesor, memory, dan monitoring Oracle. Database file bekerja sebagai tempat penyimpanan Oracle. Penyimpanan data, informasi, pengaturan, akan disimpan dengan baik, dan diatur oleh instance. Instance terbagi menjadi 2 bagian. Yang pertama adalah SGA. SGA befungsi sebagai kumpulan memory yang menjadi hal yang utama bagi instance. Bagian yang kedua adalah background process yang berfungsi untuk menjalankan Oracle. 


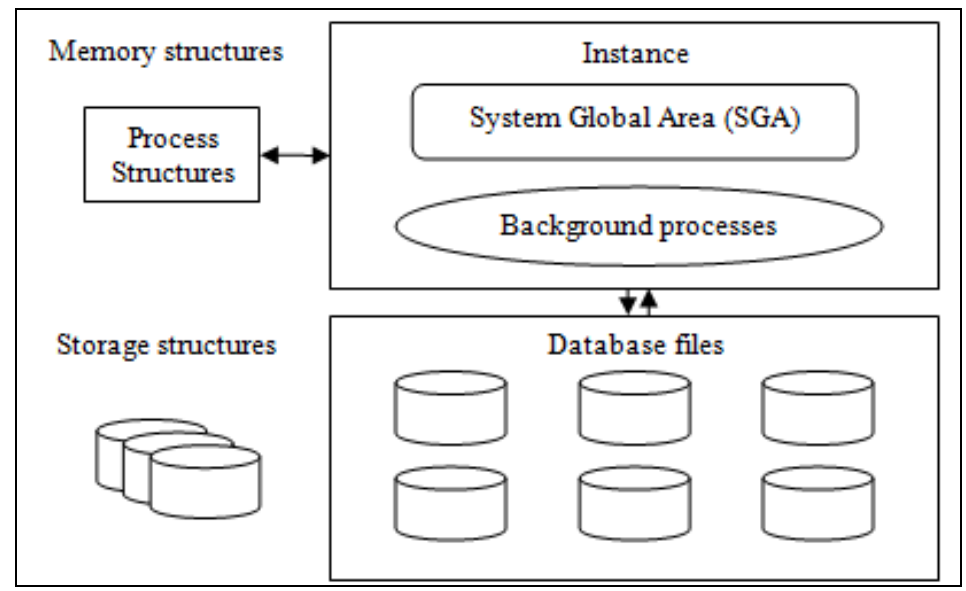

Gambar 2. Arsitektur Oracle Database

Struktur memory Oracle atau pada bagian sebelumya disebutkan sebagai SGA, terbagi menjadi 6 bagian utama yang mempunyai tugas penting seperti berikut (Best): (1) Database buffer cache. Berisi data block dari query yang diberikan oleh user, setiap user melakukan query SELECT maupun INSERT, UPDATE, DELETE, data block yang berhubungan dengan query tersebut akan dipindahkan ke buffer cache. Buffer cache akan dituliskan ke dalam data file saat LGWR bekerja. (2) Redo log buffer. Menyimpan informasi redo sampai ditulis ke dalam file physical redo log yang disimpan didalam disk. Redo yang disimpan adalah redo dari perintah DML yang diberikan user. Redo log akan dikosongkan oleh LGWR saat terjadi checkpoint. (3) Shared pool. Menyimpan berbagi macam construct yang dapat di share diantara user. (4) Large pool. Bagian yang fakultatif yang menyediakan alokasi memori yang besar untuk proses-proses yang besar, seperti operasi backup dan recovery, dan proses I/O. (5) Java pool. Digunakan untuk semua session terutama kode Java dan data dalam Java Virtual Machine (JVM). (6) Stream pool. Digunakan untuk Oracle Streams.

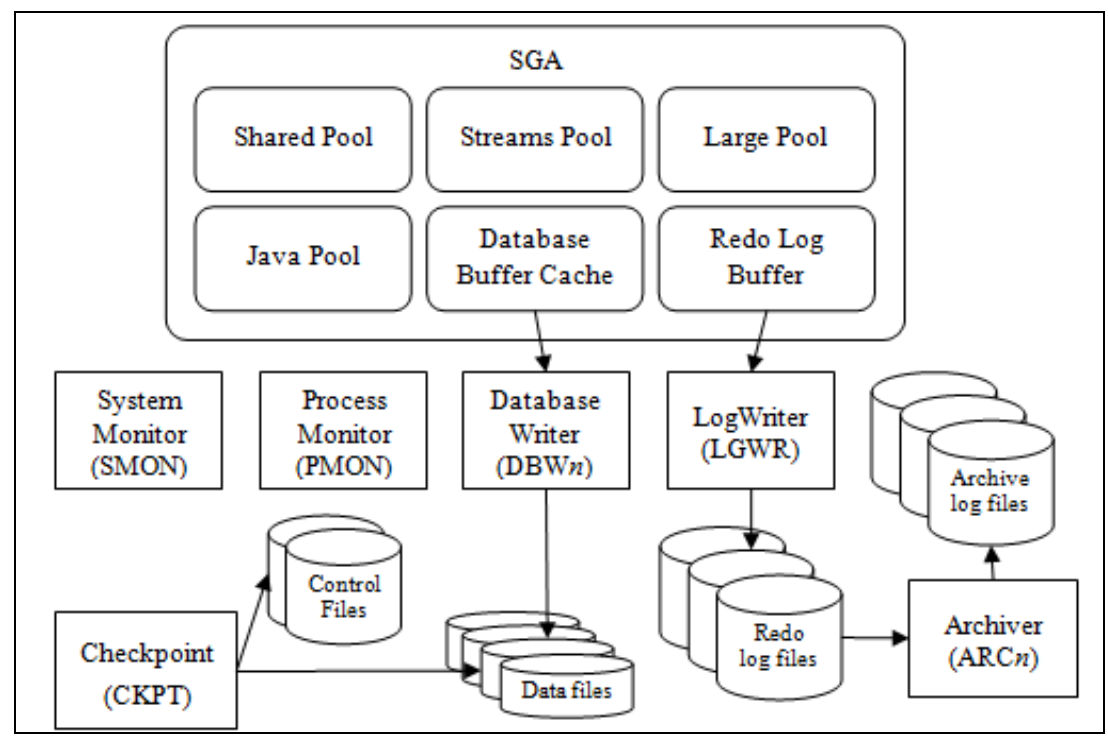

Gambar 3. Struktur Memori dan Background Proses Oracle

Sebuah Oracle instance dibentuk dari struktur memori yang dikenal dengan SGA dan background process yang menangani banyak pekerjaan dalam sebuah instance (Best). Beberapa background process yang umum adalah: (1) System Monitor (SMON). Bekerja saat instance diaktifkan setelah mengalami crash atau failure, tahap ini disebut dengan crash recovery. (2) Process Monitor (PMON). Melakukan proses pembersihan memori saat sebuah proses user 
mengalami kegagalan. (3) Database Writer (DBWn). Menuliskan block yang telah dimodifikasi dari database buffer cache ke dalam data file pada disk. (4) Checkpoint (CKPT). Memperbarui semua data file dan control file database untuk menunjukan checkpoint yang paling baru. (5) LogWriter (LGWR). Menuliskan catatan redo log ke dalam disk. Saat Oracle Data Guard diaktifkan, LGWR juga dapat bertugas untuk mengirimkan redo log file ke standby database pada mode maximum protection atau maximum availability. (6) Archiver (ARCn). Salinan file redo log ke dalam penyimpanan archival saat terjadi log switch. Archiver juga dapat bertugas untuk mengirimkan redo log file ke standby database pada mode maximum performance.

Database object seperti tabel dan index disimpan sebagai segment dalam tablespaces. Setiap segment berisi satu atau lebih extend. Sebuah extend terdiri dari sekumpulan data blocks yang berdekatan, yang berarti setiap extend hanya akan berada dalam satu data file. Data block adalah unit terkecil dari I/O dalam basis data. Ukuran data block dapat ditentukan pada waktu pembuatan basis data. Ukuran default-nya adalah $8 \mathrm{~KB}$. Jika basis data digunakan untuk aplikasi data warehouse yang mempunyai tabel dan index yang besar, maka ukuran block yang lebih besar akan sangat bermanfaat. Redo log file disimpan dalam ukuran data block, sehingga setiap kali pengiriman data dari primary database ke standby database, data yang dikirim bukan per record, melainkan sebuah data block.

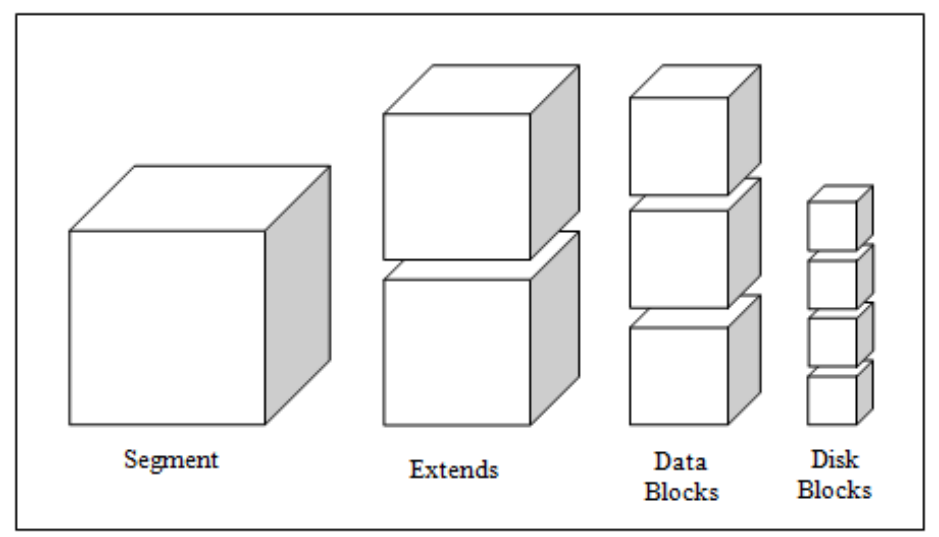

Gambar 4. Segment, Extends, Data Blocks, dan Disk Blocks

\subsection{Oracle Data Guard}

Oracle Data Guard adalah salah satu produk Oracle yang terdapat dalam instalasi Oracle Database. Oracle Data Guard adalah sebuah infrastruktur perangkat lunak yang digunakan untuk manajemen, monitoring, dan automatisasi yang berkerja bersama sebuah basis data produksi dan satu atau lebih standby database untuk melindungi data dari failure, error, dan corruption yang mungkin dapat mempengaruhi kinerja basis data.

Oracle Data Guard terbagi menjadi 2 bagian, yaitu primary database (pada bagian kiri gambar 5) dan standby database (pada bagian kanan gambar 5). Primary database bekerja secara aktif menerima semua proses transaksi dan mengirimkan data transaksi ke standby database, sedangkan standby database bekerja secara pasif dengan menerima data transaksi yang dikirimkan dari primary database. Standby database bekerja secara aktif (berubah menjadi primary database), saat primary database mengalami switchover atau failover, dan langsung bekerja tanpa membutuhkan waktu recovery. Standby database berfungsi untuk menerima redo log yang dikirimkan oleh primary database, redo log tersebut akan diterima, dan dieksekusi sendiri oleh standby database (Keesling). Oracle mempunyai dua tipe standby database yaitu physical standby database dan logical standby database.

Physical standby database secara fisik identik dengan primary database. Database struktur sama dengan primary database berdasarkan pada basis block-for-block (Keesling). Physical standby database di update berdasarkan redo data yang didapat dari primary database. 
Database ini hanya dapat digunakan untuk recovering data dan open untuk laporan read-only. Logical standby database selalu bersinkronisasi dengan primary database dengan mengubah data dari redo yang dikirimkan oleh primary database menjadi statement $S Q L$ yang kemudian dijalankan dalam standby database (Keesling). Hal ini dapat dilakukan dengan menggunakan teknologi Log Miner. Tabel dalam logical standby database dapat digunakan secara simultan untuk recovery dan keperluan lain seperti laporan, summation, dan query.

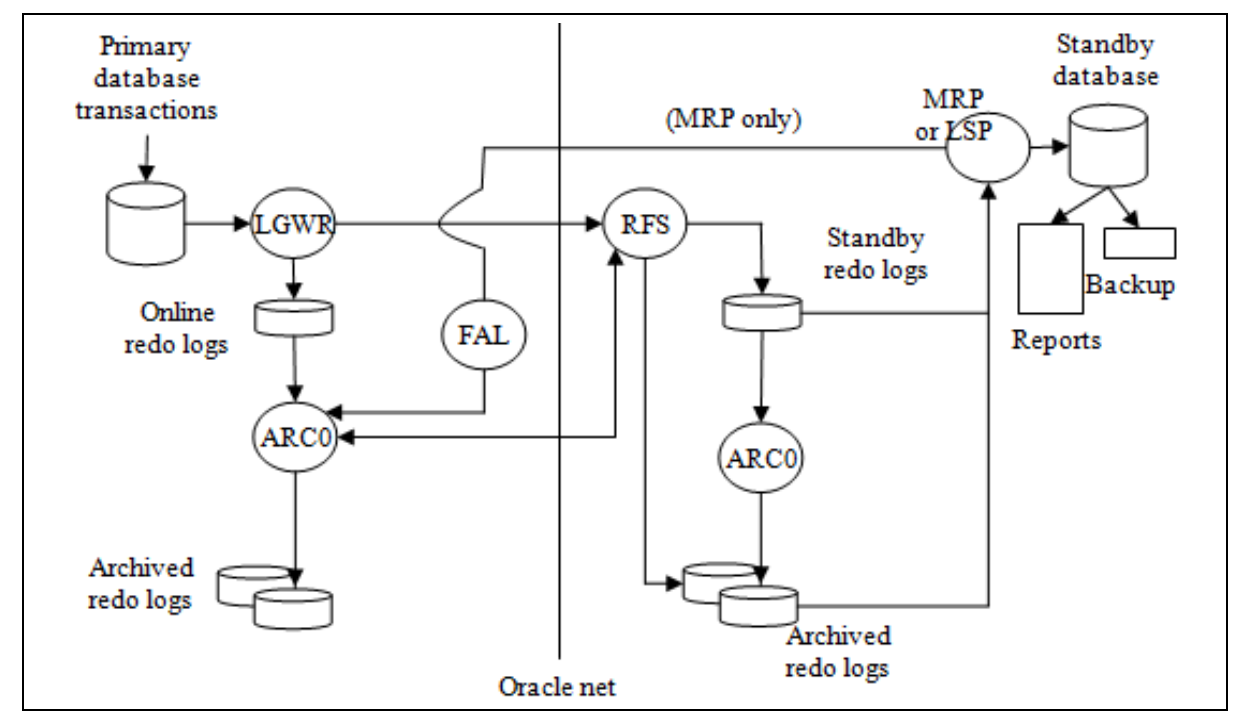

Gambar 5. Arsitektur Oracle Data Guard

Pada primary database, Data Guard log transport services menggunakan beberapa proses berikut ini (Keesling): (1) Proses log writer (LGWR). LGWR menggumpulkan redo information transaksi dan meng-update online redo logs. Dalam mode synchronous, LGWR mengirimkan informasi redo langsung ke proses remote file server (RFS) pada standby database dan menunggu konfirmasi sebelum dijalankan. Dalam mode asynchronous, LGWR mengirimkan informasi redo langsung, tetapi tanpa menunggu konfirmasi. (2) Proses archiver $(\mathrm{ARC} n)$. ARCn adalah copy dari redo logs secara lokal untuk digunakan dalam primary database recovery. Proses ARCn juga dapat mengirim redo stream ke RFS disaat yang bersamaan dengan archiving online log. ARCn juga bertugas secara proaktif untuk mendeteksi dan menyelesaikan celah log pada semua standby database. (3) Fetch archive log (FAL) (hanya pada physical standby database). FAL menyediakan sebuah mekanisme client-server untuk menyelesaikan celah log yang dideteksi dengan archived redo log yang di-generate pada primary database dan didapat pada standby database. Proses ini berjalan hanya pada saat dibutuhkan dan shutdown langsung setelah tugasnya selesai.

Pada standby database, Data Guard log apply services menggunakan beberapa proses dibawah ini (Keesling): (1) Proses Remote file server (RFS). RFS menerima redo information dari primary database. RFS dapat menuliskan redo ke dalam standby redo logs atau archived redo logs. (2) Proses archiver (ARCn). Proses ARCn meng-archive standby redo logs. (3) Managed recovery prosess (MRP). MRP meng-apply archieved redo log information ke physical standby database (hanya untuk physical standby database), dengan menggunakan perintah SQL untuk recovery "ALTER DATABASE RECOVER MANAGED STANDBY DATABASE DISCONNECT FROM SESSION”. (4) Logical standby process (LSP). LSP mengontrol apply dari archived redo log information ke logical standby database (hanya untuk logical standby database).

Pada komputer physical standby database ada 2 mode yang bisa dipilih: (1) Redo Apply. Dalam mode ini, log transport services meng-archive log ke standby database, dan log apply services secara otomatis meng-apply log ini. Database dalam state MOUNT, data tidak dapat diakses. (2) Open read-only. Digunakan untuk tujuan reporting. Log apply services tidak 
dapat meng-apply archive redo log ke standby database pada mode ini, tetapi primary database tetap mengirimkan redo ke standby database. Untuk komputer logical standby database, mempunyai kebebasan untuk memilih mode Open read/write. Pada mode ini, log apply services tetap memanajemen informasi log dari archived redo log. Mode open bisa digunakan untuk reporting.

Oracle Data Guard menyediakan mode maximum protection, maximum availability, dan maximum performance untuk membantu DBA dalam menjaga keamanan data. Dalam beberapa situasi, data sebuah bisnis menjadi sangat penting dan tidak boleh hilang. Sedangkan beberapa aplikasi yang lain membutuhkan maximum database performance dan dapat mentolerir kemungkinan kehilangan data.

Mode Maximum Protection menjamin tidak ada data yang hilang kecuali primary database fail. Untuk mengkonfigurasi tingkat proteksi ini, dibutuhkan redo data untuk merecover setiap transaksi yang harus dituliskan ke dalam local online redo log dan standby redo log pada sedikitnya satu standby database sebelum transaksi di commit. Untuk menjamin data tidak pernah hilang, primary database shut down jika ada kesalahan yang terjadi pada penulisan redo stream ke sedikitnya satu remote standby redo log. Mode Maximum Availability menyediakan tingkat proteksi keamanan data yang paling tinggi tanpa mengetahui keadaan primary database. Sama seperti maximum protection mode, sebuah transaksi tidak akan pernah commit sampai redo yang dibutuhkan untuk me-recover transaksi tersebut dituliskan ke dalam redo stream dan paling sedikit pada satu remote standby redo log. Primary database tidak akan shut down jika terjadi kegagalan dalam penulisan redo stream ke dalam standby redo log. Pengiriman redo log file akan berhenti saat terjadi kegagalan penulisan. Gap antara redo log akan diselesaikan pada saat pebaikan kegagalan tersebut. Mode ini menjamin tidak ada data yang hilang jika primary database mengalami kegagalan, hanya pengiriman redo data akan berhenti sementara sampai adanya perbaikan. Mode Maximum Performance adalah default dari Data Guard yang menyediakan proteksi tertinggi yang dapat dilakukan tanpa mengurangi performa dari primary database. Mode ini mengijinkan sebuah transaksi untuk commit saat redo data yang dibutuhkan untuk recover transaksi tersebut ditulis pada minimal satu standby database, tetapi redo stream ditulis secara asynchronous dengan sebuah kesepakatan transaksi tersebut akan membuat redo data. Mode ini digunakan pada sistem dengan bandwidth yang cukup, dengan mengurangi traffic agar performa database tetap terjaga.

Operasi switchover dan failover tidak akan berjalan secara otomatis. DBA yang harus menginisiasikan operasi switchover dan failover dengan menggunakan SQL statement atau dengan menggunakan GUI Data Guard atau dengan command-line interface (CLI) Data Guard broker.

\section{Metodologi Penelitian}

\subsection{Diagram Use Case Untuk DBA}

Selain aktor-aktor dalam Simulasi SIA-SAT, terdapat aktor tambahan yaitu DBA (database administrator) yang mengurusi basis data. Gambar 6 adalah diagram use case untuk aktor DBA, dengan beberapa use case yang penting dalam penelitian ini.

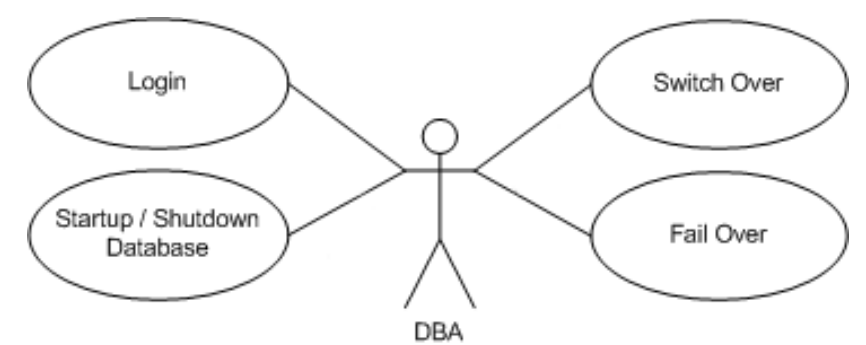

Gambar 6. Diagram Use Case DBA 


\subsection{Diagram Activity DBA}

DBA adalah seorang user yang memiliki kemampuan administrasi basis data. Secara umum mereka bertugas untuk membuat, dan merawat basis data. Aktifitas mereka dalam basis data sangat banyak, dari mulai melakukan instalasi, membuat tabel, membuat user, mengawasi kondisi basis data, melakukan backup, dan melakukan restore basis data.

Gambar 7 hanya menggambarkan sebagian kecil aktifitas yang terjadi dalam user DBA, yaitu: startup database, shutdown database, switchover, dan failover.

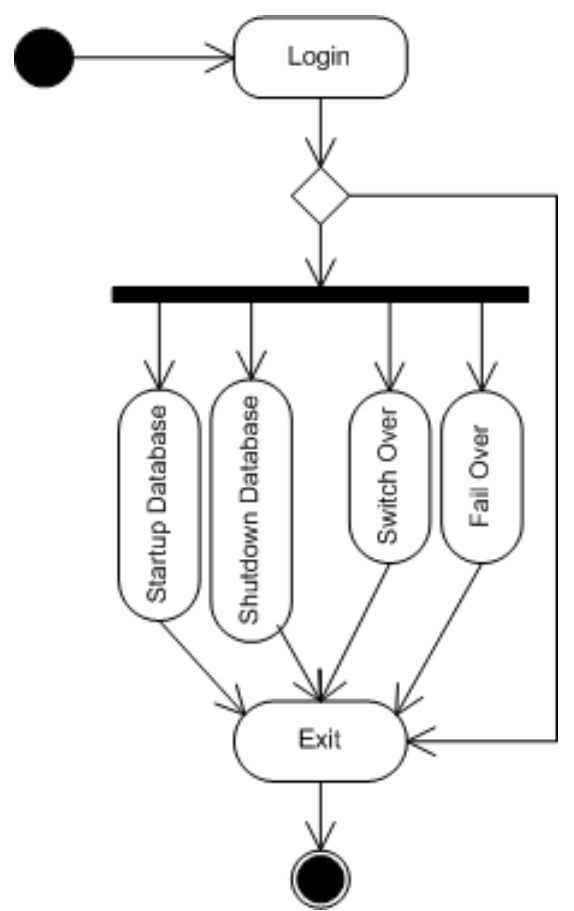

Gambar 7. Diagram Activity DBA

\subsection{Diagram Sequence DBA}

Pada diagram sequence DBA, terdapat 4 diagram, yaitu: diagram sequence login, diagram sequence startup dan shutdown immediate, diagram sequence switchover, dan diagram sequence failover. Diagram tersebut mengambarkan urut-urutan proses secara umum.

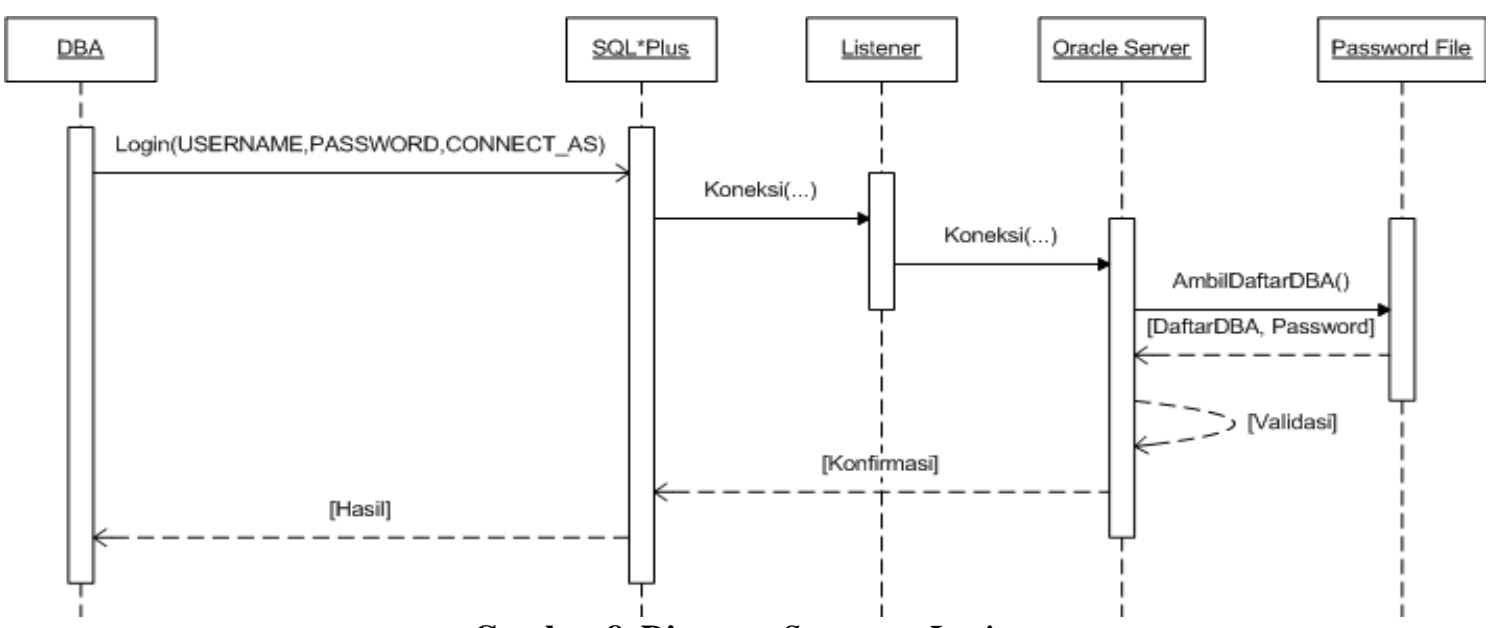

Gambar 8. Diagram Sequence Login 


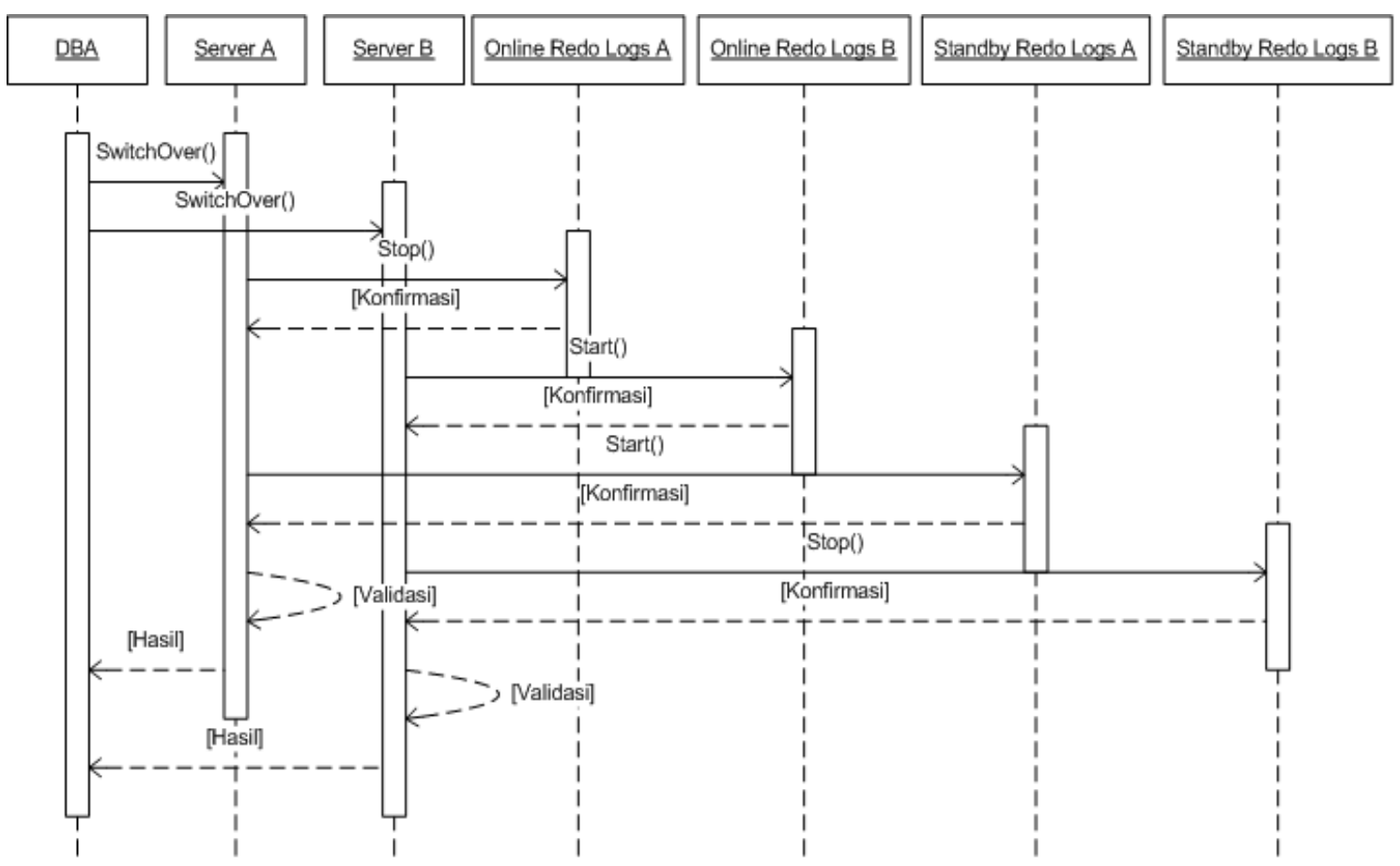

Gambar 9. Diagram Sequence Switchover

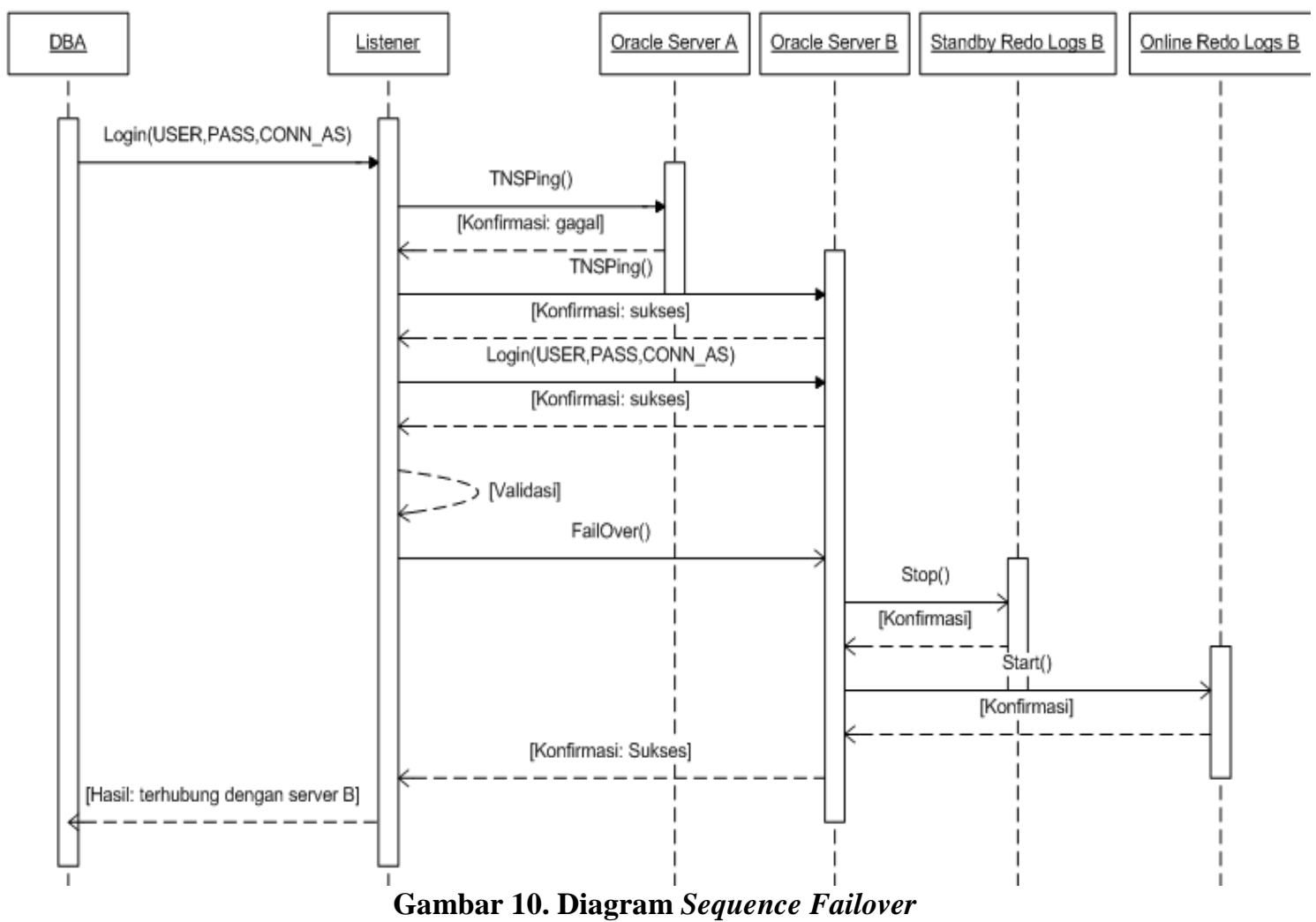

\subsection{Diagram Deployment}

Tujuan dari Oracle Data Guard adalah untuk mencapai sebuah sistem yang high availability. Untuk mengimplementasikan sistem ini, diperlukan beberapa persiapan yang harus 
dilakukan. Secara teknis, pada tahap ini yang harus dipersiapkan adalah hardware dan software untuk membangun sistem ini, yaitu server, perangkat jaringan, sistem operasi, dan software.

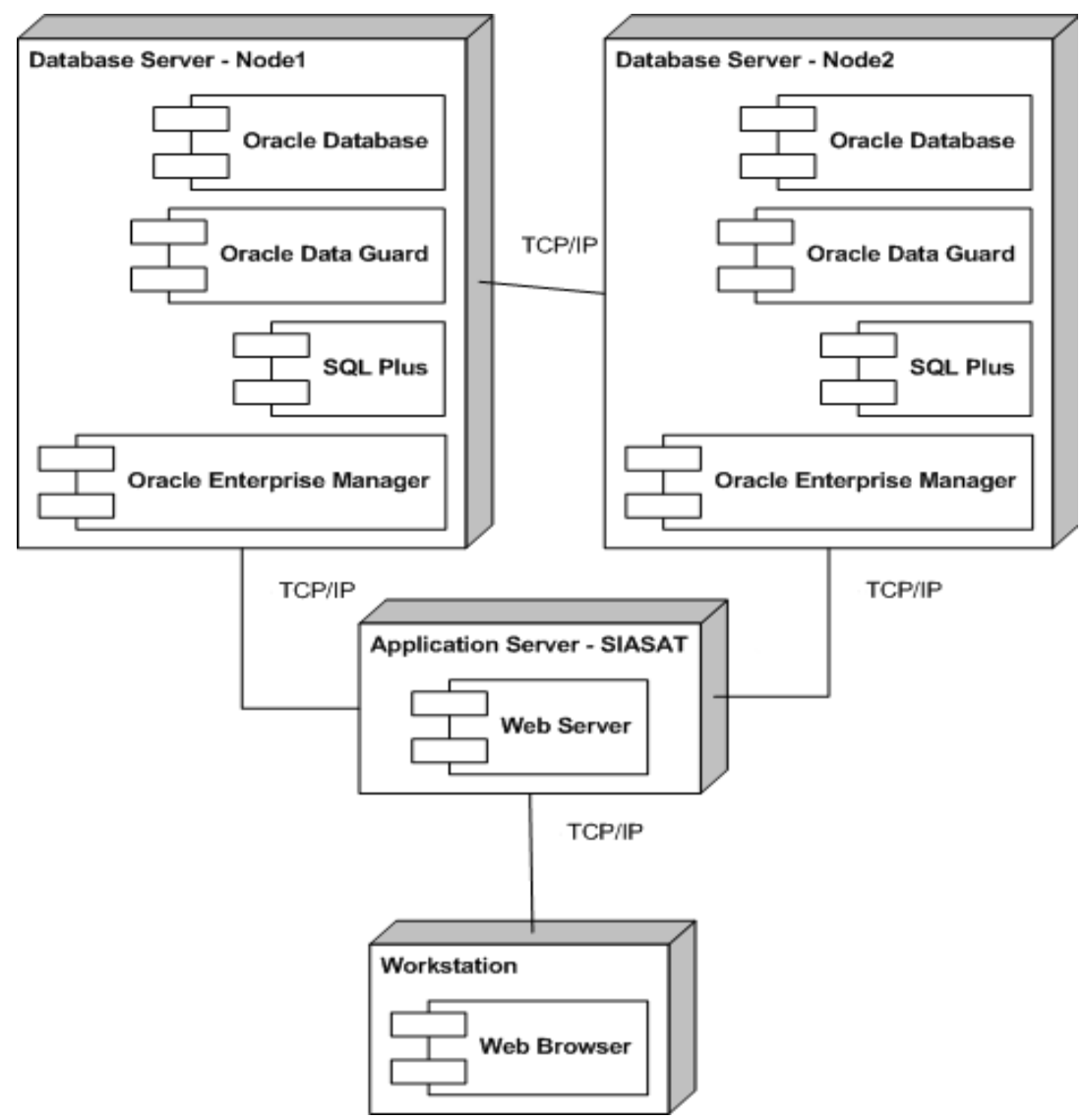

Gambar 11. Diagram Deployment

Rancangan sistem merupakan dasar bagi sistem ini. Logical design dapat diartikan sebagai konsep rancangan yang biasanya meliputi struktur jaringan, jumlah server yang akan digunakan, dan lain-lain. Physical design adalah rancangan yang lebih spesifik, contohnya adalah merk server atau NIC. Gambar 12 adalah rancangan topologi sistem Oracle Data Guard dan SIA-SAT.

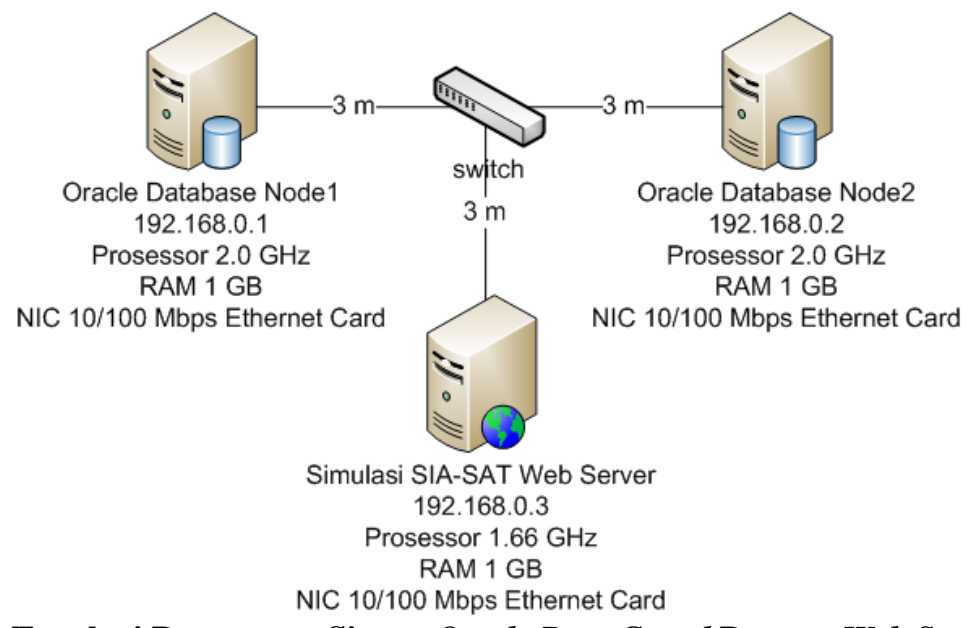

Gambar 12. Topologi Rancangan Sistem Oracle Data Guard Dengan Web Server SIA-SAT 


\section{Pengujian dan Pembahasan}

Untuk menguji apakah node1 telah terhubung dengan node2, dengan melihat status $\log$ sekarang, dan nomor log pada node1.

\begin{tabular}{|c|c|c|c|c|c|c|}
\hline \multicolumn{7}{|c|}{ SQL> select * from $\mathrm{v} \$ \log$; } \\
\hline GROUP\# & THREAD\# & SEQUENCE\# & BYTES & MEMBERS & $S$ ARC & STATUS \\
\hline \multicolumn{7}{|c|}{ FIRST_CHANGE\# FIRST_TIM } \\
\hline $\begin{array}{c}1 \\
532172\end{array}$ & $\begin{array}{c}1 \\
\text { 14-JAN-0 }\end{array}$ & 5 & 52428800 & & 1 No & INACTIVE \\
\hline $\begin{array}{c}2 \\
557887\end{array}$ & $\begin{array}{c}1 \\
\text { 14-JAN-0 }\end{array}$ & 6 & 52428800 & & 1 No & CURRENT \\
\hline $\begin{array}{c}3 \\
508917 \\
\end{array}$ & $\begin{array}{c}1 \\
\text { 14-JAN-0 } \\
\end{array}$ & 4 & 52428800 & & $1 \mathrm{~N} 0$ & INACTIVE \\
\hline
\end{tabular}

\section{Gambar 13. Status Log File Pada Node1}

Status log sequence berada pada no 6 karena statusnya pada saat ini adalah "CURRENT". Log ini disimpan dalam control file, dalam database ini mempunyai 3 buah control file. Control file selalu berganti (switch) jika terjadi dua kondisi, yakni jika control file sudah penuh, (2) Atau terjadi log switch. Jika kita melakukan perintah ALTER SYSTEM SWITCH LOGFILE, maka log sequence akan bertambah menjadi 7, hal ini dapat dilihat pada gambar 14.

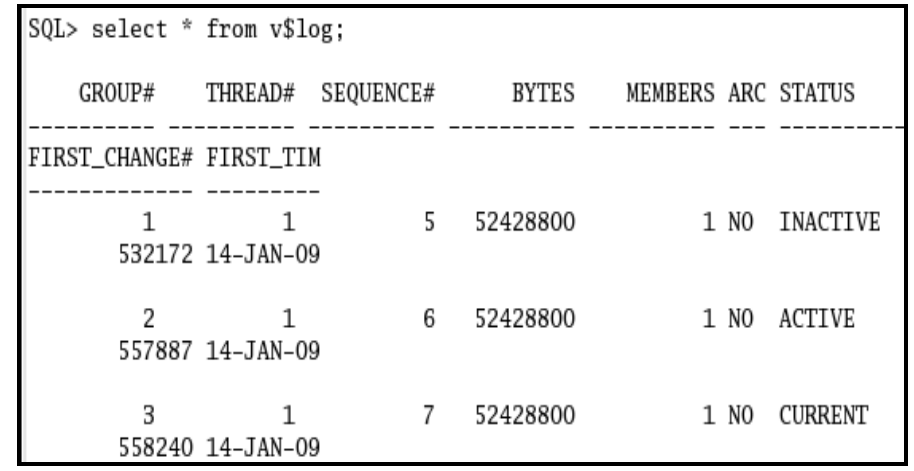

Gambar 14. Status Log File Pada Node1 dan Node2

Pada standby database (node2), basis data tidak dapat dipergunakan karena harus menunggu data dari node1, namun basis data dapat dibuka dengan status read only. Berikut adalah isi dari tabel admin pada node2.

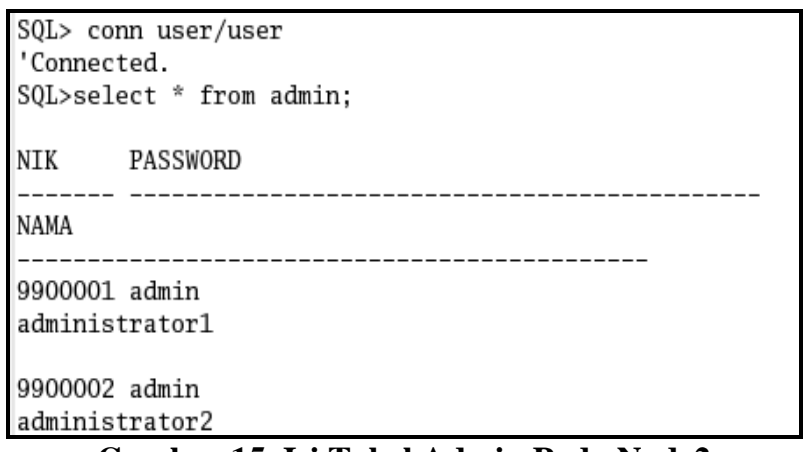

Gambar 15. Isi Tabel Admin Pada Node2 
Untuk pengujian failover, maka dalam pengujian ini, penulis melakukan pemutusan network, sehingga node1 terpisah dari jaringan. Pada SIA-SAT akan muncul pada halaman login.

\begin{tabular}{|c|c|c|c|c|}
\hline \multirow{2}{*}{\multicolumn{2}{|c|}{$\begin{array}{l}\text { SIA-SAT Home } \\
\text { Sistem Informasi Akademik Satya Wacana }\end{array}$}} & \multicolumn{3}{|c|}{$\begin{array}{r}\text { Universitas Kristen Satya Wacana } \\
\text { Wednesday, January } 14,2009\end{array}$} \\
\hline & & Home & Search & Contact \\
\hline Home & \multirow{2}{*}{ Selamat datang di SIA-SAT } & & Login & \\
\hline General & & & No. Induk & 672005128 \\
\hline penggunaan & Maaf saat ini server SIA-SAT sedang mengalami gangguan. & & Password & .......... \\
\hline \multirow{2}{*}{$\begin{array}{l}\text { Explore } \\
\text { Contact }\end{array}$} & Terima kasih atas pengertiannya. & & & Login \\
\hline & (Administrator) & & \multicolumn{2}{|c|}{ Forgot Password | Login } \\
\hline
\end{tabular}

Gambar 16. Halaman Login Pada Saat Database Beralih

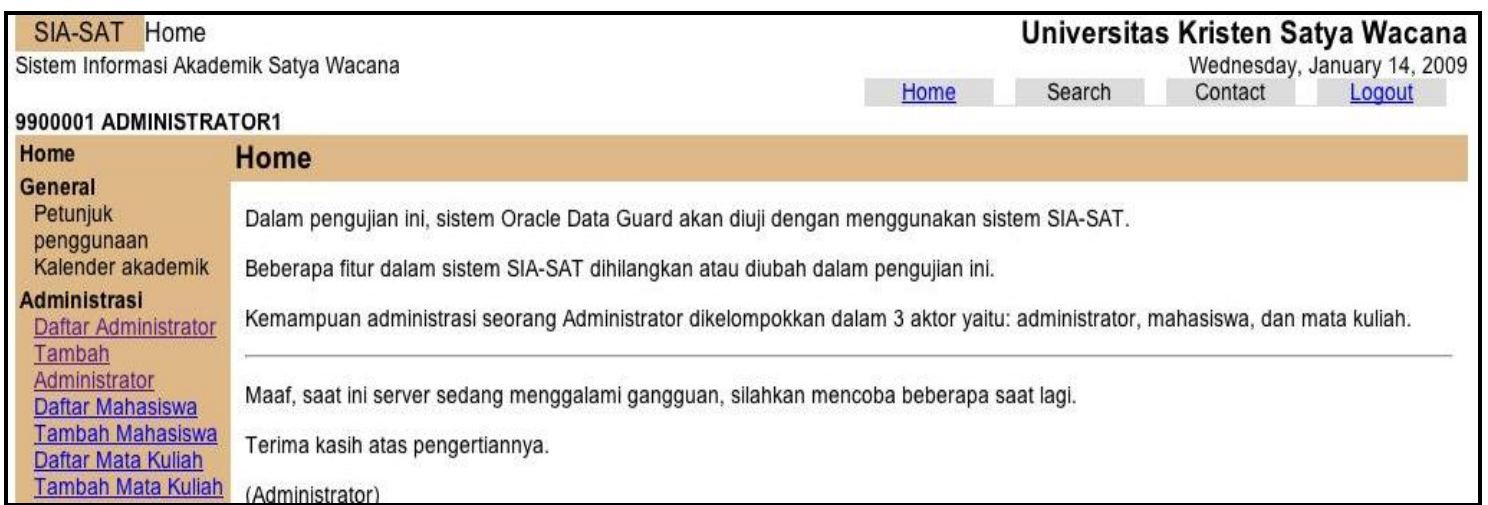

Gambar 17. Halaman Admin Saat Database Beralih

\begin{tabular}{|c|c|c|c|c|c|c|}
\hline \multicolumn{3}{|l|}{ SIA-SAT Home } & & \multicolumn{3}{|c|}{ Universitas Kristen Satya Wacana } \\
\hline \multirow{2}{*}{\multicolumn{3}{|c|}{ Sistem Informasi Akademik Satya Wacana }} & & & \multicolumn{2}{|c|}{ Wednesday, January 14,2009} \\
\hline & & & Home & Search & Contact & Logout \\
\hline \multicolumn{7}{|c|}{9900001 ADMINISTRATOR1 } \\
\hline \multirow{4}{*}{$\begin{array}{l}\text { Home } \\
\text { General } \\
\text { Petunjuk } \\
\text { penggunaan } \\
\text { Kalender akademik }\end{array}$} & \multicolumn{6}{|c|}{ Daftar Administrator } \\
\hline & NIK & Password & \multicolumn{4}{|l|}{ Nama } \\
\hline & $\times 9900001$ & admin & \multicolumn{4}{|l|}{ administrator1 } \\
\hline & $\times 9900002$ & admin & \multicolumn{4}{|l|}{ administrator2 } \\
\hline
\end{tabular}

Gambar 18. Halaman Daftar Administrator Setelah Terjadi Failover

Failover membutuhkan beberapa saat untuk dapat membuat node2 aktif untuk menggantikan node1. Simulasi SIA-SAT akan sementara berhenti, dikarenakan tidak dapat mengakses basis data hingga node2 aktif. Setelah node2 aktif, web server akan dapat mengakses basis data kembali, dan tampilan kembali seperti pada gambar 18 .

\subsection{Percobaan Failover}

Percobaan ini dilakukan dalam beberapa proses dalam web, kemudian failover dilakukan. Parameter yang menjadi pembanding adalah waktu, kondisi data, kondisi web server. Failover akan dilakukan dengan memutuskan jaringan primary database. Pemutusan jaringan dipilih karena jaringan merupakan salah satu faktor yang penting dalam sistem ini yang menjadi penghubung antara kedua basis data, dan pemutusan jaringan merupakan percobaan yang aman bagi kondisi komputer, sehingga kondisi fisik komputer tidak terganggu.

Percobaan ini dilakukan saat seorang user SIA-SAT melakukan proses insert ke database, kemudian langsung dilakukan failover beberapa detik saat hasil insert telah muncul. Percobaan ini dilakukan sebanyak 10 kali, sehingga didapat waktu rata-rata 1 menit 26 detik. 
Tabel 2. Hasil Percobaan Failover

\begin{tabular}{ccc}
\hline Menit & Detik & Availability \\
\hline 1 & 30 & $99.999707 \%$ \\
\hline 1 & 28 & $99.999714 \%$ \\
\hline 1 & 26 & $99.999720 \%$ \\
\hline 1 & 27 & $99.99717 \%$ \\
\hline 1 & 27 & $99.99717 \%$ \\
\hline 1 & 25 & $99.99724 \%$ \\
\hline 1 & 24 & $99.99727 \%$ \\
\hline 1 & 28 & $99.999714 \%$ \\
\hline Rata-rata & 1 menit 26 detik & $99.99737 \%$ \\
\hline
\end{tabular}

\subsection{Percobaan Failover Tanpa Data Guard}

Maksud dari failover tanpa data guard adalah dengan me-recovery data pada node2 secara manual dari backup terakhir pada node1, lalu pengalihan koneksi web server ke node2. Pada saat kondisi data awal, yaitu pada tabel admin hanya memiliki 1 data administrator, node 1 akan di-backup, dan backup file akan dipindah ke node2. Backup dilakukan dengan tool RMAN (Recovery Manager).

Node1 akan ditambah 1 data administrator2, dan akan matikan, sehingga web server harus mengalihkan koneksi ke node2. Pada node2, dilakukan recovery dengan menggunakan tool RMAN. Waktu rata-rata yang diperlukan untuk recover database ini adalah 10 menit 57 detik.

Tabel 3. Hasil Percobaan Failover Tanpa Oracle Data Guard

\begin{tabular}{ccc}
\hline Menit & Detik & Availability \\
\hline 10 & 43 & $99.997910 \%$ \\
\hline 11 & 6 & $99.997835 \%$ \\
\hline 10 & 9 & $99.998020 \%$ \\
\hline 11 & 12 & $99.997815 \%$ \\
\hline 10 & 32 & $99.997945 \%$ \\
\hline 11 & 13 & $99.997812 \%$ \\
\hline 10 & 35 & $99.997936 \%$ \\
\hline 10 & 42 & $99.997718 \%$ \\
\hline 11 & 53 & $99.997877 \%$ \\
\hline Rata-rata & 10 menit 57 detik & $99.997763 \%$ \\
\hline & & $99.997864 \%$
\end{tabular}

\section{Kesimpulan}

Dengan menggunakan Oracle Data Guard, proses perpindahan basis data saat terjadi failure, tidak membutuhkan proses recovery, sehingga tidak menambah waktu downtime. Hal ini dapat terjadi karena data langsung ditambahkan ke dalam data file. Terjadi peningkatan waktu uptime jika menggunakan Oracle Data Guard. Sistem ini menghemat waktu untuk recovery data. Dengan peningkatan waktu uptime, waktu pelayanan database pun akan bertambah. Data akan lebih aman jika menggunakan physical standby database, karena berfungsi sebagai replika dari primary database. Dibandingkan dengan backup yang biasa, data tidak selalu ter-update setiap saat. 


\section{Referensi}

Best, T., Billings, M.J. 2005. Oracle Database 10g: Administration Workshop I. California. Bharwara, D.I. 2001. Cluster High Availability Pada Server LTSP. Salatiga: Fakultas Teknik Elektro Universitas Kristen Satya Wacana.

Fathansyah. 2004. Sistem Basis Data. Bandung: Informatika.

Greenberg, N. 2004. Oracle Database 10g: SQL Fundamental I. California.

Han, Y. 2005. An Integrated High Availability Computing Platform. Arizona: Academic Research Library University of Arizona.

Keesling, D., Van Dyke, R. 2005. Oracle Database 10g: Data Guard Administration. California.

Koopmann, J.F. 2007. Achieving High Availability on a Linux Two-Node Cluster Using Oracle's Maximum Availability Architecture. Canada: LSI Logic Corporation.

Mannino, M.V. 2004. Database design, application development, and administration. New York: Mcgraw-Hill.

Saputra, H., Christian. 2008. Perancangan dan Implementasi Basis Data Terdistribusi Menggunakan Arsitektur SAN (Storage Area Network) pada Rekam Medis on-line. Salatiga: Fakultas Teknologi Informasi Universitas Kristen Satya Wacana. 